\title{
Microbial Biofilms in Endodontic Infections: An Update Review
}

\author{
Zahed Mohammadi ${ }^{1}$, Flavio Palazzi ${ }^{2}$, Luciano Giardino ${ }^{3}$, Sousan Shalavi ${ }^{1}$
}

\begin{abstract}
Biofilms and microbial aggregates are the common mechanisms for the survival of bacteria in nature. In other words, the ability to form biofilms has been regarded as a virulence factor. Microbial biofilms play an essential role in several infectious diseases such as pulp and periradicular pathosis. The aim of this article was to review the adaptation mechanisms of biofilms, their roles in pulpal and periapical pathosis, factors influencing biofilm formation, mechanisms of their antimicrobial resistance, models developed to create biofilms, observation techniques of endodontic biofilms, and the effects of root canal irrigants and medicaments as well as lasers on endodontic biofilms. The search was performed from 1982 to December 2010, and was limited to papers in English language. The keywords searched on Medline were "biofilms and endodontics," "biofilms and root canal irrigation," "biofilms and intra-canal medicament," and "biofilms and lasers." The reference section of each article was manually searched to find other suitable sources of information. (Biomed J 2013;36:59-70)
\end{abstract}

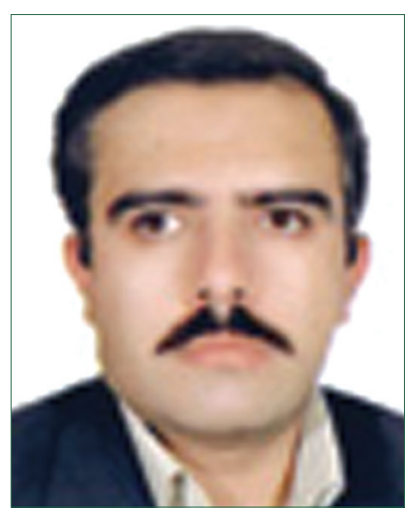

Dr. Zahed Mohammadi

\section{Key words: biofilm, intracanal medicaments, periapical infections, pulpal infections, root canal irrigation}

$\mathrm{M}$ any microorganisms are able to form surface-attached microbial communities known as biofilms. In fact, biofilms are communities of microorganisms attached to a surface and embedded in a matrix of polysaccharides and proteins, forming a slimy layer. ${ }^{[1]}$ The matrix typically takes $85 \%$ of the volume of a biofilm. ${ }^{[1]}$ Oral bacteria have the capacity to form biofilms on distinct surfaces ranging from hard to soft tissues. The characteristics of the biofilms depend upon the residing bacterial species, composition and structure of the surface or substratum, and the conditioning layer coating the surfaces on which they are formed. Water constitutes $80 \%$ of the oral biofilms, while the organic and inorganic fractions form approximately $20 \%$ of the biofilm structure. ${ }^{[2]}$

\section{Definition of biofilm}

Biofilm can be defined as a sessile multicellular microbial community characterized by cells that are firmly attached to a surface and enmeshed in a self-produced matrix of extracellular polymeric substance (EPS, usually a polysaccharide). ${ }^{[3]}$

\section{Adaptation mechanisms}

Microorganisms endure a wide range of physiological and morphological modifications in response to environmental changes. In biofilms, different gradients of chemicals, nutrients, and oxygen establish micro-environments to which the microorganisms must adjust to survive. The perception and processing of chemical information from the environment form a central part of the regulatory control of these adaptive responses. To adapt to a biofilm lifestyle, a large set of genes must be regulated and the microorganisms are thus able to optimize phenotypic properties for the particular environment. Consequently, biofilm microorganisms differ phenotypically from their planktonic counterparts ${ }^{[4]}$ Formation of biofilm is a step-wise process including deposition of a conditioning film, adhesion and colonization of planktonic microorganisms in a polymeric matrix, co-adhesion of other organisms, and detachment of biofilm microorganisms into their surroundings ${ }^{[5]}$ Evidence is emerging that expression of genes required during the various stages is well-regulated. ${ }^{[6-8]}$

\footnotetext{
From the ${ }^{1}$ Department of Endodontics, Hamedan University of Medical Sciences, Hamedan, Iran; Iranian Centre for Endodontic Research (ICER), Tehran, Iran, ${ }^{2}$ Department of Odontostomatological and Maxillofacial Sciences, Federico II University of Naples, Italy, ${ }^{3}$ Department of Endodontics, University of Torino, Italy

Received: Jul. 3, 2012; Accepted: Aug. 16, 2012

Correspondence to: Dr. Zahed Mohammadi, Department of Endodontics, School of Dentistry, Hamedan University of Medical Sciences, Hamedan, Iran. Tel: 98-9188729690; Fax: 98-8118354220; E-mail: zahed_mohammadi@yahoo.com
}

DOI: $10.4103 / 2319-4170.110400$ 


\section{Quorum sensing and biofilm formation}

Although adaptation to environmental stress by genetic transformation occurs rarely, such a rare event can be highly significant if the transforming DNA provides a selective advantage to the recipient cells. ${ }^{[9]}$ In addition to providing the community with an abundant extracellular gene pool, the biofilm environment facilitates the bacteria with a localized neighborhood where cell-cell signaling mechanisms likely abound. It has been shown that the formation of biofilms involves multiple, convergent signaling pathways and a genetic program for the transition from planktonic growth state to the biofilm mode of growth. ${ }^{[10]}$ In Gram-negative bacteria such as Pseudomonas aeruginosa, cell-cell signaling through quorum sensing has been found to play an important role in biofilm differentiation, and this sensibility affects the virulence of this bacterium. ${ }^{[11,12]}$ The influence of quorum-sensing systems on the structure of Gram-positive biofilms was first determined by a study on Streptococcus gordonii. ${ }^{[13]}$

\section{Role of extracellular dna (eDNA) in biofilm formation}

A significant fraction of the biofilm matrix can be only DNA. For example, Steinberger and Holden reported that extracellular DNA can be up to $50 \%$ more abundant than cellular DNA in unsaturated biofilms of Ps. aeruginosa ${ }^{[14]}$ For the first time, Whitchurch et al. ${ }^{[15]}$ demonstrated eDNA as a matrix component of Ps. aeruginosa biofilms. ${ }^{[15]}$ It was also reported that eDNA originates from the intracellular DNA under conditions in which lysis is not observed. ${ }^{[16]}$ In case of Staphylococcus epidermidis and Enterococcus faecalis, ${ }^{[17,18]}$ eDNA results from the autolysin-mediated killing of a small subpopulation of cells, to provide DNA as a component of biofilm matrix. eDNA can be released via autolysis and can be a major contributor to vancomycin-enhanced biofilm formation in Staphylococcus aureus. ${ }^{[19]}$

Any eDNA seen during the log phase of growth should mostly be due to active secretion mechanisms and not due to cell death. High concentration of eDNA at later stages of growth (post- $48 \mathrm{~h}$ ) can be attributed to cell lysis leading to passive release of DNA into the extracellular medium. ${ }^{[15,17,18]}$

\section{Biofilm in endodontic infections}

The most famous biofilm structure studied in the field of dentistry is dental plaque ${ }^{[5]}$ As other biofilm structures, planktonic bacteria in the saliva serve as the main source of organisms for plaque formation. ${ }^{[20]}$ In endodontics, biofilms can be divided into intracanal, external root (cementum), and periapical biofilms. ${ }^{[2]}$

\section{Intracanal biofilms}

For the first time, Nair discussed biofilm concept in endodontics. ${ }^{[21]}$ Using transmission electron microscopy (TEM), he examined the root canal content of teeth with gross coronal caries and to which the periapical inflammatory tissue was attached upon extraction. In addition to his observations of the microstructure of the inflammatory tissues, he noted that the major bulk of the organisms existed as loose collections of cocci, rods, filaments, and spirochetes. While most of these organisms appeared suspended, in a moist canal space, dense aggregates were also observed sticking to the canal walls and forming thin to thick layers of bacterial condensations. Amorphous material filled the inter-bacterial spaces and was interpreted as an extracellular matrix of bacterial origin. When present, the bacterial condensations showed a palisade structure similar to the one for dental plaque on external tooth surfaces, suggesting similar mechanisms for bacterial attachment as those for dental plaque. ${ }^{[21]}$ Sen et al. ${ }^{[22]}$ investigated the root canal walls of infected teeth by scanning electron microscopy (SEM) and found that the bacteria formed dense colonies on the canal walls as well as in intra- and inter-tubular dentin. In addition to bacteria, fungi were capable of forming dense, but separate colonies all over the root canal walls.

George et al. ${ }^{[23]}$ evaluated the ability of E. faecalis to develop biofilm under aerobic, anaerobic, nutrient-rich, and nutrient-deprived conditions. According to their findings, when E. faecalis cells were grown under aerobic nutrient-rich condition, they produced irregularly shaped amorphous macro-structures of 500-1000 $\mu \mathrm{m}$ in dimension. Under closer examination, these structures were found to be aggregates of bacterial cells. When examined by SEM and confocal laser scanning microscope (CLSM), E. faecalis specimens kept under nutrient-rich, anaerobic conditions showed mature biofilm with apparent water channels on the root canal wall. Bacterial cells suspended within the biofilm structure were evident from the laser confocal scanning microscopy (LCSM) observations. The examination of biofilms formed under nutrient-deprived, aerobic environment showed obvious signs of surface degradation of dentin. The degradation of dentin could be a result of the interactions between substrate surface, abiotic degradation products, bacterial cells, and their metabolic products in the nutrient-deprived condition. There were no clumps of aggregated intact bacterial cells on the surface of these structures in contrast to those under nutrient-rich conditions, as revealed by SEM and CLSM examinations. However, the possibility of calcified bacterial cells deposited on these structures could not be eliminated. Distel et al. ${ }^{[24]}$ found that pure cultures of $E$. faecalis inoculated to calcium hydroxide-medicated or non-medicated root canals were able to form a biofilm structure on the canal walls. Nair et al. ${ }^{[25]}$ found that even 
after instrumentation, irrigation, and obturation in a one-visit treatment, microorganisms existed as biofilms in untouched locations in the main canal, isthmuses, and accessory canals in 14 of the 16 endodontically treated teeth.

Kishen et al. ${ }^{[26]}$ investigated the interaction between E. faecalis and root canal dentin substrate. Toward this end, tooth specimens were prepared and divided into two groups. The tooth specimens in group 1 were incubated with E. faecalis for periods of 2-, 4-, and 6-week intervals, and the chemical composition of the biofilm was determined using X-ray diffraction and Fourier transform infrared (FTIR) spectroscopy. The tooth specimens in group 2 were incubated with E. faecalis for a period of 6 weeks, and the topography and ultrastructure of the biofilm were examined using SEM, light microscopy, and CLSM. The sediments from the bacterial interaction on dentin (in group 1) were also examined by SEM and FTIR. Findings demonstrated different stages in the interaction of E. faecalis with root canal dentin. Further, re-precipitation of a bacterial-induced apatite on mature biofilm was also observed. This ability of $E$. faecalis to form such calcified biofilm on root canal dentin may be a factor that contributes to its persistence.

\section{External root surface (cementum) biofilms}

These types of biofilms were reported in teeth with asymptomatic apical periodontitis, as well as in teeth with chronic apical abscesses associated with sinus tract. ${ }^{[2]}$ Tronstad et al. ${ }^{[27]}$ evaluated the surfaces of the root tips removed during surgical intervention by SEM and reported that the apex of the roots adjacent to the apical foramen was coated with a continuous, smooth, structure-less layer containing a variety of bacterial forms. Furthermore, in irregularities of the surfaces, bacteria were seen held together by an extracellular material. The organisms were identified as cocci and rods with the presence of some fibrillar forms. Ricucci et al. ${ }^{[28]}$ demonstrated the presence of calculus-like deposits on the root tip of teeth with secondary (post-treatment) apical periodontitis. Harn et al. ${ }^{[29]}$ observed calcified biofilms on the apical root surface of teeth with lesions refractory to conventional root canal treatment.

Siqueira and Lopes assessed extracted teeth with extensive caries and asymptomatic periradicular lesions using SEM. ${ }^{[30]}$ It was observed that cocci and rods were restricted to the root canal and in only one tooth; bacteria were seen beyond the apical foramen. Most bacteria appeared suspended in the fluid phase of the root canal. It was remarked that the presence of bacteria at or outside the apical foramen might not necessarily be a true condition, but rather a function of extrusion of bacterial colonies during tooth extraction. Based on their findings, extraradicular infection in terms of root tip aggregations may not be a common occurrence in untreated teeth with infected pulps.
Lomcali et al. ${ }^{[31]}$ examined the apical root surfaces of teeth with chronic apical periodontitis by SEM. Findings showed that lacunar resorption zones were frequently observed on the root surfaces. Furthermore, bacteria and yeast cells were detected in some of the lacunae. In addition, periapical bacterial plaque with a smooth structure was present mostly around the main apical foramen. This multilayered plaque had microorganisms embedded in an extracellular matrix and coated with a smooth structure. This coating was considered to be a combination of bacterial by-products and local inflammatory components. These findings suggest that host defense mechanisms may be unable to hold back the microorganisms in the root canal space, and such structures with embedded microorganisms outside the apical foramen might not be eliminated by conventional endodontic procedures and systemic antibiotic usage.

Using SEM, Leonardo et al. ${ }^{[32]}$ evaluated the root tips of extracted teeth with various pulpal conditions including vital or necrotic pulps with or without apical lesions. They found that biofilm formation was present only on teeth with apical periodontitis. These biofilms were composed of different bacterial morphotypes, viz. cocci, bacilli, and filaments. In another study, they found that the presence of chronic periapical lesions caused severe changes in the apical structure with a destruction of fibers and different degrees of cementum resorption forming lacunae in which bacterial biofilm persisted. ${ }^{[33]}$ Similar findings were also obtained in the apical regions of primary teeth. ${ }^{[34]}$ Noiri et al. ${ }^{[35]}$ analyzed the presence of biofilm formation on the root tips of extracted teeth with "refractory periapical pathosis" and gutta-percha points removed during endodontic treatment by SEM. Gutta-percha points sticking out through the apex were almost completely covered with glycocalyx-like structures. Bacteria, mostly filaments or long rods, were seen on the external root surfaces in the extracted teeth.

\section{Periapical biofilms}

These types of biofilms are isolated biofilms found in the periapical region of endodontically involved teeth. They may or may not be dependent on the root canal infection. ${ }^{[2]}$ The microbiota in the majority of teeth associated with apical periodontitis is restricted to the root canal, as most of the microbial species that infect the root canal are opportunistic pathogens that do not have the ability to survive the host defense in the periapical tissues. Rarely, microbial species or even strains within a species may possess strategies to survive, and thus infect periapical tissues. ${ }^{[2]}$ Members of the genus Actinomyces, and the species Propionobacterium propionicum have been demonstrated in asymptomatic periapical lesions refractory to endodontic treatment. ${ }^{[36]}$ This condition consists of establishment of microorganisms in the periapical tissues, either by their adherence to the 
apical root surface in the form of biofilm-like structures or within the body of the inflammatory lesion, ${ }^{[27]}$ usually as cohesive colonies. ${ }^{[37]}$

Although the exact mechanism by which Actinomyces species exert their pathogenicity has not been totally clarified, there is some evidence that can help explain infections caused by these microorganisms. Most Actinomyces species are of low virulence and their mere invasion into tissues does not usually suffice to establish an infection. However, necrotic pulps do not offer resistance to invasion by microorganisms, except for selective pressures exerted by the environmental conditions, which are arguably adequate for most Actinomyces species. Some Actinomyces species have fimbrial structures that may play a role in bacterial coaggregation within the root canal and can be important for bacterial survival in the ecosystem. In addition, fimbriae would enable Actinomyces cells to adhere to the root canal wall and to dentinal debris forced out through the apical foramen during treatment, and to cling to other bacteria or host cells as they advance into the periapical tissues. ${ }^{[38]}$

Actinomyces species usually have a hydrophobic cell surface character, which facilitates uptake by leukocytes. Figdor and Davies have investigated the ultrastructure of Actinomyces israelii by electron microscopy and reported that strains can have hair-like fimbriae protruding through a thick surface coat. ${ }^{[39]}$ Thin sectioning reveals a Gram-positive cell wall surrounded by a fuzzy outer coat. They suggest that both the fimbriae-like structures and the matrix of the outer coat surrounding the bacteria can help the cells to aggregate into cohesive colonies of tangled filaments. Moreover, strains associated with post-treatment disease have been demonstrated to grow as intertwining filaments, forming granulae within host tissues. ${ }^{[38,36,40]}$ It is believed that the ability to form branching, filamentous microcolonies may be critical for the establishment of these bacteria in the tissue. The size of bacterial aggregates is important for phagocytosis to occur. The presence of a hyaloid or hyaline layer in actinomycotic colonies may provide protection against host defenses, and it may also serve to embed the filamentous and branching microorganisms in a cohesive mass. ${ }^{[38]}$ Thus, the bacteria appear to be able to evade collectively host defenses by building in host tissues, cohesive colonies consisting of large numbers of branching and filamentous bacteria enmeshed in a matrix of protein-polysaccharide complex. ${ }^{[38]}$ Actinomycotic colonies may live in equilibrium with the host tissues without necessarily inducing an acute response, but rather maintaining a chronic periapical inflammation. Very high numbers of Actinomyces cells are usually needed to form persistent infections. ${ }^{[41]}$ The low pathogenicity of these microorganisms and the consequent minimal host response may be the reasons for the perpetuation of the chronic periapical lesion.

\section{Factors influencing biofilm formation}

From an ecological perspective, the root canal can be considered as a highly controlled environment with a limited number of niches. ${ }^{[42]}$ Therefore, for bacteria to endure endodontic treatment and be detected in post-treatment samples, they must resist intracanal disinfection procedures and adapt to the drastically changed environment. Several strategies may help bacteria to resist treatment. Bacteria can adhere to the root canal walls, accumulate, and form biofilms. ${ }^{[3]}$ Formation of biofilm is influenced by the physicochemical properties of the components involved in the biofilm. Firstly, a conditioning layer is needed. Secondly, numerous microorganisms in the planktonic phase will be transported to the surface of conditioning film. It should be noted that it is the properties of the conditioning layer that determine those microorganisms, which attach and thereby influence the microbial composition of the biofilm. ${ }^{[5]}$ Several factors can affect bacterial attachment to a solid substrate. These factors include surface energy of the substrate, temperature, $\mathrm{pH}$, flow rate of the fluid passing over the surface, length of time the bacteria are in contact with the surface, surface hydrophobicity, and nutrient availability ${ }^{[2]}$ According to Grenier and Maynard, surface structures of bacteria such as pili, flagella, ${ }^{[43]}$ and extracellular polymeric substances (EPS) play important roles in microbial adherence. Furthermore, a specific bacterial adhesion with a substrate is produced via polysaccharide adhesin or ligand formation. Adhesin or ligand on the bacterial cell surface will bind to receptors on the substrate. The third stage of biofilm formation involves multiplication and metabolism of attached microorganisms that ultimately will result in a structurally organized mixed microbial community. ${ }^{[5]}$ During this stage, the monolayer of microbes attracts secondary colonizers forming microcolony, and the collection of microcolonies gives rise to the final structure of biofilm. ${ }^{[44,45]}$

\section{Mechanisms of antimicrobial resistance}

There are several mechanisms for biofilms to resist antimicrobial agents. The polysaccharide matrix of biofilms can retard diffusion of the antibiotics. In addition, extracellular enzymes such as $\beta$-lactamase may become trapped and concentrated in the matrix, thereby inactivating $\beta$-lactam antibiotics. ${ }^{[46]}$ Furthermore, quorum sensing (communication with one another) can influence the structure of the biofilm by encouraging the growth of species beneficial to the biofilm. ${ }^{[5,47]}$ It has been shown that subpopulations of bacteria in a biofilm form a phenotypic state (altered gene expression) where they are highly protected. ${ }^{[1]}$

Bacterial cells protect themselves by being located within the interior part of a biofilm; hence, medicaments will only act on the microorganisms in the peripheral portion 
of the biofilm. Additionally, bacterial cells residing within a biofilm grow more slowly than planktonic cells, and as a result, antimicrobial agents act more slowly. ${ }^{[46]}$

Depletion of nutrients or accumulation of waste products can result in bacteria entering a non-growing state which protects the bacteria from the antibiotics. ${ }^{\left[{ }^{[8]}\right.}$ Pajkos et al. ${ }^{[49]}$ revealed that biofilm bacteria exist in a low metabolic state, with a slower growth rate and production of exopolysaccharides. Chemical changes to the environment in the biofilm are lack of oxygen inhibits some antibiotics and accumulated acidic waste leads to a difference in $\mathrm{pH}$ which has an antagonizing effect on the antibiotic. ${ }^{[50]}$

\section{Models developed to study biofilms}

There are a number of techniques to create microbial biofilms in vitro. One technique is the flow cell system. This system consists of a nutrient reservoir, a single channel flow cell, a peristaltic valve, and a waste vessel. The flow cell is a Delrin polyacetal resin channel with a rectangular glass cover slip sealed with a rubber gasket and a Delrin polyacetal resin flange. The flow channel contains eight circular recesses. Each cell contains an inoculated coupon. The flow cells are filled with sterile Todd Hewitt broth (THB) media from the reservoir by reducing the atmospheric pressure on the waste side of the flow cell by activating the peristaltic pump. Once the flow cell is filled with the media, the pump is shut off and the overnight inoculum is introduced into the bioreactor cell through a syringe injection port upstream of the coupons. The culture volume used covers all of the coupons and is maintained in the flow cell for $30 \mathrm{~min}$ to allow for bacterial attachment to the coupons. Laminar flow is resumed in an approximate flow rate of $20 \mathrm{ml} / \mathrm{h}$ to flush the inoculum from the flow cell and to allow biofilm formation on the coupons. Biofilms are grown at $37^{\circ} \mathrm{C}$ for $24 \mathrm{~h}$. Growth on each coupon is approximately $10^{8}$ colony-forming units. ${ }^{[46]}$

Another method is creation of biofilms on cellulose nitrate membranes ( $0.2 \mu \mathrm{m}$ pore size, $13 \mathrm{~mm}$ diameter). In this technique, the membranes are placed on the surface of $5 \%$ defibrinated sheep blood brain heart infusion (BHI) broth agar plates (for aerobic and facultatively anaerobic microorganisms) and on 5\% defibrinated sheep blood-fastidious anaerobe agar (FAA) plates (for strict anaerobes), and are further inoculated with $20 \mu \mathrm{l}$ of each test microorganism suspension. The plates, each containing membrane filters, are incubated at $37^{\circ} \mathrm{C}$ again under the appropriate gaseous conditions: Aerobes and facultative anaerobes in a $\mathrm{CO}_{2}$ incubator and anaerobes in an anaerobic chamber in an atmosphere of $10 \% \mathrm{H}_{2}, 10 \% \mathrm{CO}_{2}$, and $80 \% \mathrm{~N}_{2}$. ${ }^{[1]}$

Another technique was proposed by Clegg et al..$^{[52]} \mathrm{In}$ this technique, after preparing dentin sections, removing the smear layer, and sterilizing dentin sections, these sections are allowed to soak for $24 \mathrm{~h}$ in an individual container of patient's filter-sterilized saliva to develop a pellicle layer. Afterward, each specimen is placed in separate wells of tissue culture plates to which $2.5 \mathrm{ml}$ trypticase soy broth (TSB) is added. Bacteria from the patient samples are suspended in Amies solution using ultrasonic and vortex vibration for $15 \mathrm{sec}$. Then, specimens are incubated under anaerobic conditions for 7 days to allow biofilm formation. All root sections are transferred to new culture wells and fresh TSB solution is added every $48 \mathrm{~h} .{ }^{[52]}$

Recently, Estrela et al. ${ }^{[53]}$ developed a new E. faecalis biofilm system. The bacterial strain is inoculated in $7 \mathrm{ml}$ of BHI broth (Difco Laboratories, Detroit, MI, USA) and incubated at $37^{\circ} \mathrm{C}$ for $24 \mathrm{~h}$. The experimental suspensions are prepared by cultivating the biological marker on the surface of BHI agar, following the same incubation conditions. The bacterial cells are resuspended in saline to reach a final concentration of about $3 \times 10^{8}$ cells $/ \mathrm{ml}$, adjusted to No. $1 \mathrm{McFarland}$ turbidity standard. In the experimental model, a split platform is used during the period of inoculation with the biological indicator. The coronal portion of the root canal of each tooth is connected to the cut end of a $1.5 \mathrm{ml}$ polypropylene Eppendorf tube using a cyanoacrylate adhesive and epoxy resin. The tooth-tube connections are entirely coated with two layers of nail polish. The specimens (teeth plus polypropylene tubes) are sterilized in 5\% sodium hypochlorite $(\mathrm{NaOCl})$ for $30 \mathrm{~min}$ and rinsed with sterile water for $30 \mathrm{~min}$. The specimens are placed into BHI broth and the test apparatus is incubated at $37^{\circ} \mathrm{C}$ for $24 \mathrm{~h}$ to ensure sterilization. No bacterial growth is observed after this period. Five milliliters of sterile BHI broth is mixed with $5 \mathrm{ml}$ of the bacterial inoculum containing E. faecalis and inoculated using sterilized syringes of sufficient volume to fill the root canal during a 60 -day period. This procedure is repeated every $72 \mathrm{~h}$, always using 24-h pure culture prepared and adjusted to No. $1 \mathrm{McFarland}$ turbidity standard. The teeth are maintained in a humid environment at $37^{\circ} \mathrm{C}$. At 60 days, each tooth is removed from its apparatus under aseptic conditions and irrigation is done with $5 \mathrm{ml}$ of sterile distilled water with a sterile syringe. The root canals are dried and refilled with sterile distilled water. Thereafter, sterile paper points (size 45) are introduced into the root canals and maintained for $3 \mathrm{~min}$ for sample collection. Each sample is collected using three paper points, which are individually transported and immersed in $7 \mathrm{ml}$ of Letheen Broth, followed by incubation at $37^{\circ} \mathrm{C}$ for $48 \mathrm{~h}$ in a reduced oxygen atmosphere. Microbial growth is analyzed by turbidity of the culture medium. Thus, after assessing Letheen Broth changes, inoculums of $0.1 \mathrm{ml}$ obtained from the medium are transferred to $7 \mathrm{ml}$ of $\mathrm{BHI}$, and subsequently incubated at $37^{\circ} \mathrm{C}$ for $48 \mathrm{~h}$. Microbial growth is also checked by turbidity of the culture medium. Gram staining of BHI cultures is used for verification of contamination by E. faecalis. ${ }^{[33]}$ 


\section{Observation techniques of endodontic biofilms}

One of the first techniques to observe endodontic pathogens was compound light microscopy in combination with histological staining and/or sectioning. Although not powerful enough to resolve many structures within the cell, this type of microscope can be used for first stage identification of bacteria by verifying cellular morphology (e.g. rod-, coccal-, or spiral-shaped) and the reaction of an organism with the Gram stain (Brown/Brenn staining technique). ${ }^{[40]}$

Our understanding of biofilms has developed as the methods for biofilm examination and characterization have evolved. Electron microscopy has been used for the examination and characterization of biofilms on medical devices and in human infections. ${ }^{[54-57]}$ Microscopes employing electron beams have 400 times the resolving power of an optical microscope. Much of the early investigative work on biofilms relied heavily on the conventional scanning electron microscope (CSEM). In this technique, samples must be fixed, dehydrated, and dried or frozen prior to observation. (Before dehydration and drying procedures, different fixation procedures with different solutions are used to minimize the effect of dehydration.) Therefore, graded solvents (alcohol, acetone, and xylene) are used to gradually dehydrate the specimen prior to examination, since water of hydration is not compatible with the vacuum used with the electron beam. Solvent replacement of water removes extracellular polymeric material and this dehydration process results in significant sample distortion and artifacts. ${ }^{[58]}$ Thus, the extracellular polymeric substances, which are approximately $95 \%$ water ${ }^{[59]}$ appear more as fibers than as a thick gelatinous matrix surrounding the cells. Finally, sample preparation implies that specimens may not preserve their native state. As a result, therapeutic endodontic strategies cannot be observed or tested in situ. To overcome these shortcomings, another version of SEM, environmental SEM (ESEM) has been introduced. The major advantage of ESEM is that hydrated tissues such as biological tissues and root canal bacteria can be imaged in their "native" state. ${ }^{[60]}$ However, images of hydrated samples may not be distinct and clear in ESEM because these samples cannot be resolved well. Some additional procedures may be required to overcome these problems. ${ }^{[61]}$

Another electron microscopic technique is transmission electron microscopy (TEM). In TEM, like CSEM, in order to prevent development of artifacts, samples must be prepared prior to observation. Common preparation procedures of specimens for TEM involve relatively complex and long laboratory processing. ${ }^{[60]}$ Fixed and dehydrated specimens are generally embedded in an epoxy resin and stained with heavy metals (e.g., potassium permanganate or osmium tetroxide) to improve image contrast before ultra-thin sectioning using an ultramicrotome with glass or diamond knives. ${ }^{[25]}$ For endodontic microbial research, these sections have also been stained with tannic acid and ruthenium red staining prior to examination in the microscope ${ }^{[62,63]}$ Other preparation techniques that can be used are cryosectioning and freeze fracturing (followed by freeze etching and the production of a replica). ${ }^{[62,64]}$

The use of TEM and specific polysaccharide stains like ruthenium red allowed researchers both to identify the nature of the extracellular fibers in biofilms and to better elucidate their association with the cells. Because of its excellent resolution properties, the electron microscope will, in spite of its limitations, continue to be an important tool for the biofilm scientist.

Another technique called confocal laser scanning microscope (CLSM) has provided the ability to examine biofilms in situ without the limitations encountered with the SEM, albeit at lower magnifications. ${ }^{[64]}$ CLSM is now being used to determine the true architecture of plaque and the location of selected bacteria within the biofilm. ${ }^{[65]}$ The trade-off in resolution is more than offset by the ability to examine the biofilm matrix unaltered and intact. ${ }^{[64]}$ The use of CLSM requires that the organisms in the biofilms be stained with fluorescent stains. These stains are designed to emit light at specific wavelengths and can be used to probe specific cellular functions. Using a suite of such stains allows the biofilm researcher to quantify all the cells and determine which ones are viable. ${ }^{[64]}$

Atomic force microscopy (AFM) is another technique that does not require special specimen processing. This contact type of scanning probe microscopy has been used to obtain micrographs of dried bacteria in ambient air and living ones in their culture medium at resolutions similar to that of SEM. ${ }^{[60]}$ Using AFM, a specimen placed on an $\mathrm{XYZ}$ piezoelectric translator is scanned below a stylus mounted on a cantilever spring, and surface features cause the stylus to deflect the cantilever during scanning. This bending movement is measured by observing the angular deflection of a laser beam reflected at the back end of the cantilever. By feedback, the $\mathrm{Z}$ motion of the XYZ translator is controlled, and the contact force between the tip and the specimen surface is kept almost constant. In the end, a true 3D image of the sample surface is reconstructed from the collected data.

Fluorescent antisera and fluorescent in situ hybridization (FISH) probes may enable us to identify specific organisms within a mixed biofilm community. Green fluorescent protein, a constitutively produced, plasmid-mediated molecule, can allow biofilms to be examined noninvasively, without fixation or staining. ${ }^{[66]}$

Another technique relies on removal of the biofilms or biofilm-associated organisms from the substratum by some type of mechanical force, such as vortexing or sonication, 
prior to examination and measurement. The most commonly used procedure for measurement of biofilms is the viable plate count procedure, in which the resuspended and dispersed biofilm cells are plated onto a solid microbiological medium, incubated, and counted. ${ }^{[64]}$

Other methods have been used by biofilm researchers for measuring biofilms, including total protein, ${ }^{[67]}$ absorbance at either $550 \mathrm{~nm}$ or $950 \mathrm{~nm},{ }^{[68,69]}$ tryptophan fluorescence, ${ }^{[70]}$ endotoxin, ${ }^{[71]}$ and total adenosine triphosphate (ATP).

\section{Effects of endodontic irrigants and medicaments on biofilms}

Antimicrobial agents have often been developed and optimized for their activity against fast-growing, dispersed populations containing a single microorganism..$^{[5,72]}$ However, microbial communities grown in biofilms are remarkably difficult to eradicate with antimicrobial agents, and microorganisms in mature biofilms can be notoriously resistant for reasons that have yet to be adequately explained. There are reports showing that microorganisms grown in biofilms could be 1000-1500 times more resistant to antimicrobials than planktonically grown bacteria. ${ }^{[4,24]}$

Spratt et al. ${ }^{[73]}$ evaluated the effectiveness of $\mathrm{NaOCl}(2.25 \%), 0.2 \%$ chlorhexidine gluconate (CHX), $10 \%$ povidone iodine, $5 \mathrm{ppm}$ colloidal silver, and phosphate-buffered saline (PBS) solution (as control) against monoculture biofilms of five root canal isolates including Prevotella intermedia, Peptostreptococcus micros, Streptococcus intermedius, Fusobacterium nucleatum, and E. faecalis. Results showed that $\mathrm{NaOCl}$ was the most effective antimicrobial, followed by the iodine solution. Clegg et al. ${ }^{[52]}$ evaluated the effectiveness of three concentrations of $\mathrm{NaOCl}(6 \%, 3 \%$, and $1 \%), 2 \% \mathrm{CHX}$, and BioPure MTAD on apical dentin biofilms in vitro. Their findings indicated that $6 \% \mathrm{NaOCl}$ was the only irrigant capable of both rendering the bacteria nonviable and physically removing the biofilm.

Ozok et al. ${ }^{[74]}$ compared growth and susceptibility to different concentrations of $\mathrm{NaOCl}$ of mono- and dual-species biofilms of $F$. nucleatum or Pe. micros in vitro at $24 \mathrm{~h}$ or $96 \mathrm{~h}$. Results revealed that although at $24 \mathrm{~h}$, dual-species biofilms had similar viable counts to those of monospecies biofilms, they were more resistant to $\mathrm{NaOCl}$. At 96 h, both microorganisms had higher viable counts and were more resistant to $\mathrm{NaOCl}$ in dual-species biofilms than in monospecies biofilms of the same microorganism. As the age of the biofilms increased, so did their resistance to $\mathrm{NaOCl}$. Mixed-species biofilms of $F$. nucleatum and Pe. micros showed a time-dependent synergy in growth and resistance to $\mathrm{NaOCl}$. Dunavant et al. ${ }^{[46]}$ evaluated the efficacy of $6 \%$ $\mathrm{NaOCl}, 1 \% \mathrm{NaOCl}$, Smear Clear, 2\% CHX, REDTA, and MTAD (a mixture of a tetracycline isomer, an acid and a detergent) against $E$. faecalis biofilms using a novel in $v i$ tro testing system. Biofilms grown in a flow cell system were submerged in test irrigants for either $1 \mathrm{~min}$ or $5 \mathrm{~min}$. There was a significant relationship between test agent and percentage kill of the biofilm bacteria. No significant relationship between time and percentage kill was found. The percentage kill of the biofilms bacteria was: $6 \% \mathrm{NaO}$ $\mathrm{Cl}(>99.99 \%), 1 \% \mathrm{NaOCl}$ (99.78\%), Smear Clear (78.06\%), $2 \%$ CHX (60.49\%), REDTA (26.99\%), and MTAD (16.08\%). There was a significant difference between $1 \%$ and $6 \%$ $\mathrm{NaOCl}$, and all other agents including Smear Clear, 2\% CHX, REDTA, and MTAD. Therefore, both $1 \% \mathrm{NaOCl}$ and $6 \% \mathrm{NaOCl}$ were more efficient in eliminating $E$. faecalis biofilm than the other solutions tested. Giardino et al. [75] evaluated the efficacy of $5.25 \% \mathrm{NaOCl}$ and MTAD against E. faecalis biofilm and found that only $5.25 \%$ $\mathrm{NaOCl}$ can disaggregate and remove the biofilm every time. Using SEM and CLSM, Distel et al. ${ }^{[24]}$ found that E. faecalis was able to form biofilm in root canals despite intracanal dressing with $\mathrm{Ca}(\mathrm{OH})_{2}$. On the other hand, Chai et al. ${ }^{[76]}$ found that $\mathrm{Ca}(\mathrm{OH})_{2}$ was $100 \%$ effective in eliminating $E$. faecalis biofilm. Brandle et al. ${ }^{[77]}$ investigated the effects of different growth conditions on the susceptibility of five taxa to alkaline stress. E. faecalis, Streptococcus sobrinus, Candida albicans, Actinomyces naeslundii, and F. nucleatum were grown as planktonic cells, allowed to adhere to dentin for $24 \mathrm{~h}$, and grown as monospecies or multispecies biofilms on dentin under anaerobic conditions with a serum-enriched nutrient supply at $37^{\circ} \mathrm{C}$ for 5 days. In addition, suspended biofilm microorganisms and 5-day-old planktonic multispecies cultures were used. Microbial recovery upon direct exposure to saturated calcium hydroxide solution ( $\mathrm{pH} 12.5$ ) for 10 and 100 min was compared with control exposure to physiological saline. Findings showed that planktonic microorganisms were most susceptible; only E. faecalis and C. albicans survived in saturated solution for $10 \mathrm{~min}$, the latter also survived for $100 \mathrm{~min}$. Dentin adhesion was the major factor in improving the resistance of $E$. faecalis and A. naeslundii to calcium hydroxide, whereas the multispecies context in a biofilm was the major factor in promoting resistance of $S t r$. sobrinus to the disinfectant. In contrast, the $C$. albicans response to calcium hydroxide was not influenced by the growth condition. Adherence to dentin and interspecies interactions in a biofilm appeared to differentially affect the sensitivity of microbial species to calcium hydroxide. In a root section model, Sen et al. investigated the antifungal properties of $0.12 \mathrm{CHX}^{[78]}$ and $1 \%$ and $5 \% \mathrm{NaOCl}$ in the presence or absence of smear layer. They concluded that presence of smear layer and concentrations of $\mathrm{NaOCl}$ were important factors in determining the antifungal properties of the solutions. Williamson et al. ${ }^{[79]}$ evaluated the 
susceptibility E. faecalis biofilms against four antimicrobial irrigants. Biofilms were subjected to 1-, 3-, and 5-min exposures to one of the following irrigants: $6 \% \mathrm{NaOCl}, 2 \%$ $\mathrm{CHX}$ or one of the two new products, $<6 \% \mathrm{NaOCl}$ with surface modifiers (Chlor-XTRA) or 2\% CHX with surface modifiers (CHX-Plus ${ }^{\mathrm{TM}}$ ) (Vista Dental Products, Racine, WI, USA). Results indicated that $6 \% \mathrm{NaOCl}$ and Chlor-EXTRA $^{\mathrm{TM}}$ were significantly superior against $E$. faecalis biofilms compared to $2 \% \mathrm{CHX}$ and $\mathrm{CHX}-\mathrm{Plus}^{\mathrm{TM}}$ at all time points except $5 \mathrm{~min}$. Arias-Moliz et al. ${ }^{[80]}$ evaluated the minimal biofilm eradication concentration (MBEC) of $\mathrm{NaOCl}$, chlorhexidine, ethylenediaminetetraacetic acid (EDTA), and citric and phosphoric acids after 1, 5, and 10 min of exposure to biofilms of E. faecalis. The biofilms grew in the MBEC high-throughput device for $24 \mathrm{~h}$ at $37^{\circ} \mathrm{C}$ and were exposed to 10 serial twofold dilutions of each irrigating solution. The viable cell counts were $\log _{10}$ transformed, and a concentration of an irrigant was considered to eradicate the biofilms when it produced a reduction of $\geq 5$ logarithmic units. Findings showed that $\mathrm{NaOCl}$ was the most effective agent, capable of eradicating the biofilms after $1 \mathrm{~min}$ at a concentration of $0.00625 \%$. CHX eradicated biofilm after $5 \mathrm{~min}$ at 2\%. EDTA and citric and phosphoric acid solutions were not effective against the biofilms at any concentration or time tested. Bryce et al. ${ }^{[81]}$ evaluated the relative disruption and bactericidal effects of $\mathrm{NaOCl}$, chlorhexidine, EDTA, and iodine on single- and dual-species biofilms of root canal isolates (Streptococcus sanguinis, E. faecalis, F. nucleatum, and Porphyromonas gingivalis). Findings showed that gram-negative obligate anaerobe species were more susceptible to cell removal than gram-positive facultative anaerobes. The majority of cells were disrupted after the first minute of exposure; however, the extent varied according to the agent and species. The most effective agent at disrupting biofilms was $\mathrm{NaOCl}$. Iodine was generally effective at bacterial killing, but not disruption. Chavez de Paz et al. ${ }^{[82]}$ found that $1 \%$ $\mathrm{NaOCl}$ affected the membrane integrity of E. faecalis, Lactobacillus paracasei, Streptococcus anginosus, and Streptococcus gordonii, and removed most biofilm cells. Exposure to EDTA $(50 \mathrm{mmol} / \mathrm{l})$ affected the membrane integrity in all organisms, but failed to remove more than a few cells in the biofilms of E. faecalis, L. paracasei, and Str. anginosus. Chlorhexidine $(2.5 \%)$ had a mild effect on the membrane integrity of E. faecalis and removed only $50 \%$ of its biofilm cells. The effects were substratum-dependent, and most organisms displayed increased resistance to the antimicrobials on collagen-coated surfaces. Prabhakar et al. ${ }^{[83]}$ found that $5 \% \mathrm{NaOCl}$ was more effective against E. faecalis biofilm formed on tooth structure. Furthermore, Triphala, green tea polyphenols (GTP) and MTAD showed statistically significant antibacterial activity. Liu et al. ${ }^{[84]}$ showed that biofilms of starved E. faecalis cells were more resistant to $5.25 \% \mathrm{NaOCl}$ than those of stationary cells, and the impact of $5.25 \% \mathrm{NaOCl}$ on them decreased as the biofilm matured. Ozdemir et al. ${ }^{[85]}$ demonstrated that combination of EDTA and $\mathrm{NaOCl}$ significantly reduced the amount of intracanal biofilm in both young and old age groups. However, the bacterial counts of E. faecalis in the old group were still higher. Soares et al. ${ }^{\left[{ }^{[6]}\right.}$ revealed that the irrigation regimen based on the alternating use of $\mathrm{NaOCl}$ and EDTA seems to be promising for elimination of root canal E. faecalis biofilms. Shrestha et al. ${ }^{[87]}$ showed the efficacy of the nanoparticulates (chitosan and zinc oxide) to reduce biofilm bacteria, disrupt biofilm structure, and retain the antibacterial property even after aging. Ferrer-Lugue et al. ${ }^{[88]}$ evaluated the in vitro capacity of maleic acid (MA) as well as the combinations of cetrimide (CTR) with MA, citric acid, and EDTA in eradicating E. faecalis biofilms. According to their findings, MA eradicated $E$. faecalis biofilms at a concentration of $0.88 \%$ after $30 \mathrm{sec}$ and at $0.11 \%$ after 2 min of contact time. When combined with $0.2 \%$ CTR, it eradicated the biofilms at all three times of exposure. The combination of $0.2 \%$ CTR with either $15 \%$ EDTA or $15 \%$ citric acid gave $100 \%$ bacterial kill after 1 min of contact with the biofilms. Lundstrom et al. ${ }^{[89]}$ assessed the bactericidal efficacy of $0.04 \%$ stabilized chlorine dioxide, $3 \% \mathrm{NaOCl}, 2 \% \mathrm{CHX}$, and sterile distilled water in a polymicrobial biofilm model. Findings showed that bactericidal activity of $\mathrm{NaOCl}$ was significantly greater than that of stabilized chlorine dioxide $\left(\mathrm{ClO}_{2}\right)$ group for Str. sanguinis, Actinomyces Viscosus, and Prevotella nigrescens. Results for F. nucleatum and Pe. micros were not significant after the adjustment for multiple comparisons. Baca et al. ${ }^{[90]}$ evaluated the residual antimicrobial activity and the capacity to eradicate $E$. faecalis biofilm of several irrigation solutions $(2.5 \% \mathrm{NaOCl}, 2 \%$ chlorhexidine, $0.2 \%$ CTR, $17 \%$ EDTA, $7 \%$ MA, and regimens of $2.5 \% \mathrm{NaOCl}$ followed by $17 \%$ EDTA or $7 \%$ MA and $0.2 \%$ CTR or $2 \%$ chlorhexidine). Results showed that a $2 \% \mathrm{CHX}$ and $0.2 \%$ CTR solution showed $100 \%$ biofilm inhibition and $2.5 \%$ $\mathrm{NaOCl}$ showed the lowest residual activity $(18.10 \%)$. The kill percentage of $2.5 \% \mathrm{NaOCl}$ and $0.2 \%$ CTR was $100 \%$, followed by $7 \%$ MA and 2\% CHX, whereas 17\% EDTA was the least effective (44\%). Solutions of 7\% MA or $17 \%$ EDTA, followed by $0.2 \%$ CTR or $2 \%$ CHX showed $100 \%$ residual and antimicrobial activity.

On the whole, it seems that $\mathrm{NaOCl}$ is the only endodontic irrigant that can disrupt and remove microbial biofilm from the infected root canals.

\section{Effect of lasers on biofilms}

Seal et al. ${ }^{[1]}$ compared the bacterial killing of Str. intermedius biofilms in root canals using lethal photosen- 
sitization with various combinations of photosensitizer concentration and laser light dose or $3 \% \mathrm{NaOCl}$ irrigation. Findings showed that the combined use of a photosensitizing agent and a low-power laser directed at the access cavity was bactericidal to Str. intermedius biofilms in root canals, but was unable to achieve total kill, unlike $3 \% \mathrm{NaOCl}$. Araki et al. ${ }^{[92]}$ evaluated the effect of Er: YAG laser on the apical root third of newly extracted teeth to eliminate microbial contamination on the root apex surface and found that it may be considered an effective tool for removal of apical biofilm.

In an ex vivo study, Bergmans et al. ${ }^{[93]}$ found that endodontic pathogens that grew as biofilms were difficult to eradicate even upon direct laser exposure. Soukos et al. ${ }^{[94]}$ investigated the effects of photodynamic therapy (PDT) on endodontic pathogens in planktonic phase as well as on E. faecalis biofilms in experimentally infected root canals of extracted teeth. Strains of microorganisms were sensitized with methylene blue $(25 \mu \mathrm{g} / \mathrm{ml})$ for $5 \mathrm{~min}$, followed by exposure to red light of $665 \mathrm{~nm}$ with an energy fluence of $30 \mathrm{~J} /$ $\mathrm{cm}^{2}$. Methylene blue fully eliminated all bacterial species with the exception of E. faecalis (53\% killing). The same concentration of methylene blue in combination with red light $\left(222 \mathrm{~J} / \mathrm{cm}^{2}\right)$ was able to eliminate $97 \%$ of E. faecalis biofilm bacteria in root canals using an optical fiber with multiple cylindrical diffusers that uniformly distributed light at 360 . Noiri et al. ${ }^{[95]}$ examined the effect of Er: YAG laser against biofilms made of A. naeslundii, E. faecalis, Lactobacillus casei, Propionibacterium acnes, F. nucleatum, Po. gingivalis, or Pr. nigrescens in vitro. Findings demonstrated that the Er: YAG laser was effective against biofilms of six of the bacterial species examined, with the exception of those formed by $L$. casei. After irradiation, the number of viable cells in the biofilms was significantly decreased, whereas atrophic changes in bacterial cells and reduction in biofilm cell density were seen morphologically. They concluded that Er: YAG lasers might be suitable for clinical application as a suppressive and removal device of biofilms in endodontic treatments. ${ }^{[95]}$

On the whole, although most studies support the efficacy of lasers against endodontic biofilms, further studies should be conducted to confirm their efficacy.

\section{REFERENCES}

1. Portentier I, Waltimo TM, Haapasalo M. Enterococcus faecalis: The root canal survivor and 'star' in post-treatment disease. Endod Topics 2003;6:135-59.

2. Ingle JI, Bakland LK, Baumgartner JC. Endodontics. PMPH-USA, St. Louis $6^{\text {th }}$ ed, 2008. p. 268-85.

3. Siqueira JF, Rocas IN. Clinical implications and microbiology of bacterial persistence after treatment procedures. J Endod 2008;34:1291-301.
4. Li YH, Chen YY, Burne RA. Regulation of urease gene expression by Streptococcus salivarius growing in biofilms. Environ Microbiol 2000;2:169-77.

5. Svensater G, Bergenholtz G. Biofilms in endodontic infections. Endod Topics 2004;9:27-36.

6. Davey ME, O'Toole GA. Microbial biofilms: From ecology to molecular genetics. Microbiol Mol Biol Rev 2000;64:847-67.

7. Stoodley P, Sauer K, Davies DG, Costerton JW. Biofilms as complex differentiated communities. Annu Rev Microbiol 2002;56:187-209.

8. Sauer K, Camper AK, Ehrlich GD, Costerton JW, Davies DG. Pseudomonas aeruginosa displays multiple phenotypes during development as a biofilm. J Bacteriol 2002;184:1140-54.

9. Dowson, CG, Barcus V, King S, Pickerill P, Whatmore A, Yeo M. Horizontal gene transfer and the evolution of resistance and virulence determinants in Streptococcus. Society Appl Bacteriol Sympos Series 1997;26:42-51

10. O'Toole GA, Kolter R. Initiation of biofilm formation in Pseudomonas fluorescens WCS365 proceeds via multiple, convergent signalling pathways: A genetic analysis. Mol Microbiol 1998;28:449-61.

11. Parsek MR, Greenberg EP. Acyl-homoserine lactone quorum sensing in gram-negative bacteria: A signaling mechanism involved in associations with higher organisms. Proc Natl Acad Sci U S A 2000;97:8789-93.

12. Kumar R, Chhibber S, Harjai K. Quorum sensing is necessary for the virulence of Pseudomonas aeroginosa during urinary tract infection. Kidney Int 2009;76:286-92.

13. Loo CY, Corliss DA, Ganeshkumar N. Streptococcus gordonii biofilm formation: Identification of genes that code for biofilm phenotypes J Bacteriol 2000;182:1374-82

14. Steinberger RE, Holden PA. Extracellular DNA in single- and multiple-species unsaturated biofilms. Appl Environment Microbiol 2005;71:5404-10.

15. Whitchurch CB, Tolker-Nielsen T, Ragas PC, Mattick JS. Extracellular DNA required for bacterial biofilm formation. Science 2002;295:1487.

16. Hara T, Ueda S. A study on the mechanism of DNA excretion from $P$. aeruginosa KYU-1. Effect of mitomycin C on extracellular DNA production. Agricult Biol Chem 1981;45:2457-61.

17. Qin Z, Ou Y, Yang L. Role of autolysin-mediated DNA release in biofilm formation of Staphylococcus epidermidis. Microbiology 2007; 153:2083-92.

18. Thomas VC, Hiromasa Y, Harms N, Thurlow L, Tomich J, Hancock LE. A fratricidal mechanism is responsible for eDNA release and contributes to biofilm development of Enterococcus faecalis. Mol Microbiol 2009;72:1022-36.

19. Hsu CY, Lin MH, Chen CC. Vancomycin promotes the bacterial autolysis, release of extracellular DNA, and biofilm formation in vancomycin-non-susceptible Staphylococcus aureus," FEMS Immunol Med Microbiol 2011;63:236-47.

20. Bowden GH, Hamilton IR. Survival of oral bacteria. Crit Rev Oral Biol Med 1998;9:54-84.

21. Nair PN. Light and electron microscopic studies on root canal flora and periapical lesions. J Endod 1987;13:29-39. 
22. Sen BH, Piskin B, Demirci T. Observation of bacteria and fungi in infected root canals and dentinal tubules by SEM. Endod Dent Traumatol 1995;11:6-9.

23. George S, Kishen A, Song KP. The role of environmental changes on mono-species biofilm formation on root canal wall by Enterococcus faecalis. J Endod 2005;31:867-72.

24. Distel JW, Hatton JF, Gillespie MJ. Biofilm formation in medicated root canals. J Endod 2002;28:689-93.

25. Nair PN, Henry S, Cano V, Vera J. Microbial status of apical root canal system of human mandibular first molars with primary apical periodontitis after "one-visit" endodontic treatment. Oral Surg Oral Med Oral Pathol Oral Radiol Endod 2005;99:231-52.

26. Kishen A, George S, Kumar R. Enterococcus faecalis: Mediated biomineralized biofilm formation on root canal dentine in vitro. J Biomed Mat Res Part A 2006;77:406-15.

27. Tronstad L, Barnett F, Cervone F. Periapical bacterial plaque in teeth refractory to endodontic treatment. Endod Dent Traumatol 1990;6:73-7.

28. Riccuci D, Martorano M, Bateal AL, Pascon EA. Calculus-like deposit on the apical external root surface of teeth with post-treatment apical periodontitis: Report of two cases. Int Endod J 2005;38:262-71.

29. Harn W, Chen YH, Yuan K. Calculus-like deposit at apex of tooth with refractory apical periodontitis. Endod Dent Traumatol 1998;14:237-40.

30. Siqueira JF, Lopes HP. Bacteria on the apical root surfaces of untreated teeth with periapical lesions. A scanning electron microscopic study. Int Endod J 2001;34:216-20.

31. Lomcali G, Sen BH, Cankaya H. Scanning electron microscopic observations of apical root surfaces of teeth with apical periodontitis. Endod Dent Traumatol 1996;12:70-6.

32. Leonardo MR, Rossi MA, Silva LA, Ito IY, Bonifácio C. EM evaluation of bacterial biofilm and microorganisms on the apical external root surface of human teeth. J Endod 2002;28:815-8.

33. Leonardo MR, Rossi MA, Bonifácio KC, DA Silva LA, Assed S. Scanning electron microscopy of the apical structure of human teeth. Ultrastructur Pathol 2007;31:321-5.

34. Rocha CT, Rossi MA, Leonardo MR, Rocha LB, Nelson-Filho P, Silva LA. Biofilm on the apical region of roots in primary teeth with vital and necrotic pulps with or without radiographically evident apical pathosis. Int Endod J 2008;41:664-9.

35. Noiri Y, Ehara A, Kawahara T, Takemura N, Ebisu S. Participation of bacterial biofilms in refractory and chronic periapical periodontitis. J Endod 2002;28:679-83.

36. Siqueira JF. Periapical actinomycosis and infection with Propionobacterium Propionicum. Endod Topics 2003;6:78-95.

37. Figdor D. Apical periodontitis: A very prevalent problem. Oral Surg Oral Med Oral Pathol Oral Radiol Endod 2002;94:651-2.

38. Figdor D, Sjögren U, Sörlin S, Sundqvist G, Nair PN. Pathogenicity of Actinomyces israelii and Arachnia propionica: Experimental infection in guinea pigs and phagocytosis and intracellular killing by human polymorphonuclear leukocytes in vitro. Oral Microbiol Immunol 1992;7:129-36.

39. Figdor D, Davies J. Cell surface structures of Actinomyces israelii. Aust Dent J 1997;42:125-8
40. Ricucci D, Bergenholtz G. Bacterial status in root-filled teeth exposed to the oral environment by loss of restoration and fracture or caries: A histobacteriological study of treated cases. Int Endod J 2003;36:787-802.

41. Behbehani MJ, Jordan HV. Comparative pathogenicity of Actinomyces species in mice. J Med Microbiol 1982;15:465-73.

42. Chavez de Paz L. Redefining the persistent infection in root canals: Possible role of biofilm communities. J Endod 2007;33:652-62.

43. Grenier D, Maynard D. Nutritional relationships between oral bacteria. Infect Immun 1986;53:616-20.

44. Costerton JW, Stewart PS, Greenberg EP. Bacterial biofilm: A common cause of persistent infections. Science 1999;284:318-22.

45. Cowan M, Taylor KG, Doyle RJ. Energetic of the initial phase of adhesion of Streptococcus sanguis to hydroxyapatite. J Bacteriol 1987;169:2995-3000.

46. Dunavant TR, Regan JD, Glickman GN, Solomon ES, Honeyman AL Comparative evaluation of endodontic irrigants against Enterococcus faecalis biofilms. J Endod 2006;32:527-31

47. Larsen L. Susceptibility of porphyromonas gingivalis in biofilms to amoxicillin, doxycycline and metronidazole. Oral Microbiol Immunol 2002; 17:267-71

48. Portenier I, Waltimo TM, Haapasalo M. Enterococcus faecalis: The root canal survivor and 'star' in post-treatment disease. Endod Topics $2003 ; 6: 135-59$

49. Pajkos A, Vickery K, Cossart Y. Is biofilm accumulation on endoscope tubing a contributor to the failure of cleaning and decontamination? J Hospital Infect 2004;58:224-9.

50. Athanassiadis B, Abbott PV, Walsh LJ. The use of calcium hydroxide, antibiotics and biocides as antimicrobial medicaments in endodontics. Aust Dent J 2007;52:64-82.

51. Sena NT, Gomes BP, Vianna ME, Berber VB, Zaia AA, Ferraz CC, et al. In vitro antimicrobial activity of sodium hypochlorite and chlorhexidine against selected single-species biofilms. Int Endod J 2006;39:878-85

52. Clegg MS, Vertucci FJ, Walker C, Belanger M, Britto LR. The effect of exposure to irrigant solutions on apical dentine biofilms in vitro. J Endod 2006;32:434-7.

53. Estrela C, Sydney GB, Figueiredo JA, Estrela CR. A model system to study antimicrobial strategies in endodontic biofilms. J Appl Oral Sci 2009;17:87-91.

54. Raad I, Costerton W, Sabharwal U, Sacilowski M, Anaissie W, Bodey GP. Ultrastructural analysis of indwelling vascular catheters: A quantitative relationship between luminal colonization and duration of placement. J Infect Dis 1993;168:400-7.

55. Stickler D, Morris N, Moreno MC, Sabbuba N. Studies on the formation of crystalline bacterial biofilms on urethral catheters. Eur J Clin Microbiol Infect Dis 1998;17:649-52.

56. Ferguson DJ, Mccolm AA, Ryan DM, Acred P. A morphological study of experimental staphylococcal endocarditis and aortitis. II. Interrelationship of bacteria, vegetation and cardiovasculature in established infections. Br J Exp Pathol 1986;67:679-86.

57. Nickel JC, Costerton JW. Coagulase-negative staphylococcus in chronic prostatitis. J Urol 1992;147:398-401.

58. Little BJ, Wagner PA, Ray RI, Pope R, Scheetz R. Biofilms: An ESEM evaluation of artifacts introduced during SEM preparation. 
J Industr Microbiol 1992;8:213-22.

59. Characklis WG, Marshall KC. Biofilms: A basis for an interdisciplinary approach, In: Characklis WG, Marshall KC editors. Biofilms. New York, N.Y: John Wiley and Sons; 1990. p. 3-15.

60. Bergmans L, Moisiadis P, Van Meerbeek B, Quirynen M, Lambrecht P. Microscopic observation of bacteria: Review highlighting the use of environmental SEM. Int Endod J 2005;38:775-88.

61. Priester JH, Horst AM, Van de Werfhorst LC, Saleta JL, Mertes LA, Holden PA. Enhanced visualization of microbial biofilms by staining and environmental scanning electron microscopy. J Microbiol Methods 2007;68:577-87.

62. Haapasalo M. Bacteroides buccae and related taxa in necrotic root canal infections. J Clin Microbiol 1986;24:940-4.

63. Sunde P, Olsen I, Debelian G, Tronstad L. Microbiota of periapical lesions refractory to endodontic therapy. J Endod 2002;28:304-10.

64. Donlan RM, Costerton JW. Biofilms: Survival mechanisms of clinically relevant microorganisms. Clin Microbiol Rev 2002;15:167-93.

65. Marsh PD. Dental plaque as a microbial biofilm. Caries Res 2004;38:204-11.

66. Bloemberg GV, O’Toole GA, Lugtenberg BJ, Kolter T. Green fluorescent protein as a marker for Pseudomonas spp. Appl Environ Microbiol 1997;63:4543-51.

67. Mittelman MW, Kohring LL, White DC. Multipurpose laminar-flow adhesion cells for the study of bacterial colonization and biofilm formation. Biofoul 1992;6:39-51.

68. Jacobs L, Debruyn EE, Cloete TE. Spectrophotometric monitoring of biofouling. Water Sci Technol 1996;34:533-40.

69. Taylor RJ. Efficacy of industrial biocides against bacterial biofilms. Ph.D. thesis, University of Birmingham, Birmingham, United Kingdom, 1996.

70. Angell P, Arrage AA, Mittelman MW, White DC. On line, non-destructive biomass determination of bacterial biofilms by fluorometry. J Microbiol Methods 1993;18:317-27.

71. Rioufol C, Devys C, Meunier G, Perraud M, Goullet D. Quantitative determination of endotoxins released by bacterial biofilms. J Hospital Infect 1999;43:203-9.

72. Gilbert P, Das J, Foley I. Biofilm susceptibility to antimicrobials. Adv Dent Res 1997;11:160-7.

73. Spratt DA, Pratten J, Wilson M, Gulabivala K. An in vitro evaluation of the antimicrobial efficacy of irrigants on biofilms of root canal isolates. Int Endod J 2001;34:300-7.

74. Ozok AR, Wu MK, Luppens SB, Wesselink PR. Comparison of growth and susceptibility to sodium hypochlorite of mono- and dual-species biofilms of Fusobacterium nucleatum and Peptostreptococcus (micromonas) micros. J Endod 2007;33:819-22.

75. Giardino L, Ambu E, Savoldi E, Rimondini R, Cassanelli C, Debbia EA. Comparative evaluation of antimicrobial efficacy of sodium hypochlorite, MTAD, and Tetraclean against Enterococcus faecalis biofilm. J Endod 2007;33:852-5.

76. Chai WL, Hamimah H, Cheng SC, Salam AA, Abdullah M. Susceptibility of Enterococcus faecalis biofilm to antibiotics and calcium hydroxide. J Oral Sci 2008;49:161-6.

77. Brandle N, Zehnder M, Weiger R, Waltimo T. Impact of growth conditions on susceptibility of five microbial species to alkaline stress. J Endod 2008;34:579-82.
78. Sen BH, Safavi KE, Spangberg LS. Antifungal effects of sodium hypochlorite and chlorhexidine in root canals. J Endod 1999;25:235-8.

79. Williamson A, Cardon JW, Drake DR. Antimicrobial susceptibility of monoculture biofilms of a clinical isolate of Enterococcus faecalis. J Endod 2009;35:95-7.

80. Arias-Moliz MT, Ferrer-Luque CM, Espigares-García M, Baca P. Enterococcus faecalis biofilms eradication by root canal irrigants. J Endod 2009;35:711-4.

81. Bryce G, O’Donnell D, Ready D, Ng YL, Pratten J, Gulabivala K. Contemporary root canal irrigants are able to disrupt and eradicate single- and dual-species biofilms. J Endod 2009;35:1243-8.

82. Chávez de Paz LE, Bergenholtz G, Svensäter G. The effects of antimicrobials on endodontic biofilm bacteria. J Endod 2010;36:70-7.

83. Prabhakar J, Senthilkumar M, Priya MS, Mahalakshmi K, Sehgal PK, Sukumaran VG. Evaluation of antimicrobial efficacy of herbal alternatives (Triphala and green tea polyphenols), MTAD, and 5\% sodium hypochlorite against Enterococcus faecalis biofilm formed on tooth substrate: An in vitro study. J Endod 2010;36:83-6.

84. Liu H, Wei X, Ling J, Wang W, Huang X. Biofilm formation capability of Enterococcus faecalis cells in starvation phase and its susceptibility to sodium hypochlorite. J Endod 2010;36:630-5.

85. Ozdemir HO, Buzoglu HD, Calt S, Stabholz A, Steinberg D. Effect of ethylenediaminetetraacetic acid and sodium hypochlorite irrigation on Enterococcus faecalis biofilm colonization in young and old human root canal dentin: In vitro study. J Endod 2010;36:842-6.

86. Soares JA, Roque DE, Carvalho MA, Cunha-Santos SM, Mendonça RM, Ribeiro-Sobrinho AP, et al. Effectiveness of chemomechanical preparation with alternating use of sodium hypochlorite and EDTA in eliminating intracanal Enterococcus faecalis biofilm. J Endod 2010;36:894-8.

87. Shrestha A, Shi Z, Neoh KG, Kishen A. Nanoparticulates for antibiofilm treatment and effect of aging on its antibacterial activity. J Endod 2010;36:1030-5.

88. Ferrer-Luque CM, Arias-Moliz MT, González-Rodríguez MP, Baca P. Antimicrobial activity of maleic acid and combinations of cetrimide with chelating agents against Enterococcus faecalis biofilm. J Endod 2010;36:1673-5.

89. Lundstrom JR, Williamson AE, Villhauer AL, Dawson DV, Drake DR. Bactericidal activity of stabilized chlorine dioxide as an endodontic irrigant in a polymicrobial biofilm tooth model system. J Endod 2010;36:1874-8.

90. Baca P, Junco P, Arias-Moliz MT, González-Rodríguez MP, Ferrer-Luque CM. Residual and antimicrobial activity of final irrigation protocols on Enterococcus faecalis biofilm in dentin. J Endod 2011;37:363-6.

91. Seal GJ, Ng YL, Spratt D, Bhatti M, Gulabivala K. An in vitro comparison of the bactericidal efficacy of lethal photosensitization or sodium hypochlorite irrigation on Streptococcus intermedius biofilms in root canals. Int Endod J 2002;35:268-74.

92. Araki AT, Ibraki Y, Kawakami T, Marques JL. Er: YAG laser irradiation of the microbiological apical biofilm. Braz Dent J 2006; 17:296-9.

93. Bergmans L, Moisiadis P, Teughels W, Van Meerbeek B, Quirynen M, Lambrecht P. Bactericidal effect of Nd: YAG laser 
irradiation on some endodontic pathogens ex vivo. Int Endod $\mathrm{J}$ 2006;39:547-57.

94. Soukos NS, Chen PS, Morris JT, Ruggiero K, Abernethy AD, Som S. Photodynamic therapy for endodontic disinfection. J Endod
2006;32:979-84

95. Noiri Y, Katsumoto T, Azakami H, Ebisu S. Effects of Er: YAG laser irradiation on biofilm-forming bacteria associated with endodontic pathogens in vitro. J Endod 2008;34:826-9. 